\title{
Construindo o Panteão dos Heróis Nacionais: monumentos à República, rituais cívicos e o ensino de História
}

Building the Pantheon of National Heroes: monuments to the Republic, Civil Rites and Teaching of History

Ricardo Oriá*

\section{Resumo}

$\mathrm{O}$ artigo tem como objetivo analisar a construção de uma dada memória nacional, alicerçada na ideia de um panteão da pátria e na edificação de monumentos históricos, para o culto cívico a determinados personagens - os "heróis e filhos ilustres da nação”, geralmente ligados aos segmentos dominantes da sociedade. Ao lado dos museus nacionais, dos arquivos e das bibliotecas e, até mesmo, da instituição da história como disciplina no currículo escolar, consideramos que essa prática de construção de monumentos aos heróis, aliado à instituição de datas comemorativas e efemérides no calendário anual, foi um instrumento usado para se criar entre os cidadãos republicanos um sentimento de pertencimento ao Estado nacional e desenvolvimento de uma consciência cívico-patriótica que começava na escola, mas que deveria se estender a outros espaços públicos da cidade.

Palavras-chave: panteão da pátria; monumentos históricos; culto cívico aos heróis; datas e efemérides; ensino de história.

\section{Abstract}

The article aims to analyse the construction of one a given national memory, grounded on idea of Patria Pantheon and on edification of historical monuments, to the civic cult to certain characters the "Illustrious sons and heroes of nation", usually linked with dominant segments of society. Alongside the national museums, of files and library and, even of history institutions as a subject in the school curriculum, we consider this practice of construction of heroes monuments ally to institution of commemorative dates and ephemerides on annual calendar, was a tool used to create between the republican citizen a feeling of belonging with national state and development the awareness patriotic civic what starts in the school, but should be extending to others cities public places.

Keywords: patria pantheon; historical monuments; civic cult to heroes; ephemerides and dates; History teaching.

\footnotetext{
* Doutor em História da Educação - Centro Cultural Câmara dos Deputados.groof@uol.com.br
} 
Em 1891, no decorrer dos trabalhos de nossa primeira Constituinte Republicana, eis que surge, durante o debate parlamentar, a ideia de se construir um Panteão para o culto cívico aos grandes homens da Pátria brasileira. A proposta era de autoria do deputado Aristides Lobo. Como forma de homenagear um dos próceres do movimento republicano, Lobo propôs a criação de um Panteão ao fundador da República - Benjamin Constant (1836-1891) -, conforme relato em tribuna de outro deputado, Baptista da Motta:

No dia seguinte ao da morte deste grande brazileiro republicano, em plena sessão da constituinte, o saudoso Deputado Aristides Lobo apresentou ao Congresso a seguinte indicação, e é para essa indicação que eu peço a V. Ex a faça com que a comissão dê o parecer respectivo. Entre outros, o art. $3^{\circ}$ a que me refiro, diz o seguinte:

"Que seja creado um Pantheon em honra aos grandes homens da Patria Brazileira, onde serão inumados os que assim bem merecerem da Patria, conforme decretarem os futuros Congressos, sendo desde já indicado o Dr. Benjamin Constant." (Motta, 1911)

A medida proposta pelos deputados constituintes de 1891 dá continuidade à criação de uma simbologia para o recém-instalado regime republicano que necessitava de heróis, signos e imagens para sua legitimação perante a sociedade. Nesse sentido, as palavras da historiadora Valéria Salgueiro são bastante elucidativas:

O Congresso Constituinte republicano punha em prática, dessa forma, o princípio positivista de veneração cívica através do culto a homens ilustres em substituição à adoração dos santos católicos, erguendo-lhes um panteão do mesmo modo que tradicionalmente se erguiam templos às divindades míticas religiosas. Seguiam, assim, o princípio de Augusto Comte de que "os vivos são sempre, e cada vez mais, governados pelos mortos”. (Salgueiro, 2008, p.100)

Embora não tenha sido, de fato, criado um panteão cívico em homenagem aos grandes homens da História do país, sendo o primeiro a ser alçado a essa condição Benjamin Constant, a Constituição de 1891 determinou, em seu art. $8^{\circ}$ das Disposições Transitórias, que: "O Governo Federal adquirirá para a Nação a casa em que faleceu o Dr. Benjamin Constant Botelho de Magalhães 
e nela mandará colocar uma lápide em homenagem à memória do grande patriota - o fundador da República”.

Segundo Enders (2014, p.281), o próprio presidente da República, Marechal Deodoro, decretou uma série de medidas em favor de Benjamin Constant e sua família, uma vez que esta se encontrava em dificuldade financeira após sua morte. Entre essas medidas, constava, também, a construção de um monumento em sua homenagem que deveria ser erguido no centro da praça onde fora proclamada a República, bem como a compra de um imóvel no bairro de Santa Teresa, onde supostamente o movimento republicano fazia suas reuniões, para transformá-lo em museu. ${ }^{1} \mathrm{O}$ monumento a Benjamin Constant somente foi inaugurado em 1926 e hoje se encontra no Campo de Santana, na cidade do Rio de Janeiro.

Nos últimos anos, no contexto da renovação da historiografia brasileira, surgiram diversos estudos e pesquisas, com novas interpretações e abordagens acerca do papel da memória na construção da identidade nacional. O presente texto objetiva contribuir para o entendimento da memória e da sacralização do passado como elementos de afirmação da identidade da nação (Canclini, 1995), tendo como referência o culto cívico que se faz a determinados nomes da História, sua elevação à condição de herói nacional e as consequências desse fato para a construção da cultura histórica escolar.

Como bem assinalou o historiador francês Pierre Nora, celebrações, comemorações, rituais cívicos, efemérides, estátuas, monumentos históricos e panteões constituem, por excelência, o que ele convencionou denominar de "lugares de memória" (1993, p.13). ${ }^{2}$ Tomamos, portanto, como objeto de análise um "lugar de memória" da nacionalidade brasileira e pouco conhecido da grande maioria da população. Trata-se do Panteão da Liberdade e da Democracia Tancredo Neves, mais conhecido como "Panteão da Pátria", localizado na capital da República. Nele se encontra um livro de aço denominado "Livro dos Heróis da Pátria”, onde estão inscritos nomes de personagens históricos que, em vida, se dedicaram ao "ideário da liberdade e da democracia”. Nesse livro já se encontram os nomes de Tiradentes, Marechal Deodoro da Fonseca, Zumbi dos Palmares, D. Pedro I, Plácido de Castro, Duque de Caxias e Getúlio Vargas, dentre outros - fruto de projetos de lei que tramitaram no Congresso Nacional, desde a década de 1990. 


\section{O Que É UM Panteão?}

A ideia de glorificar os feitos e realizações dos governantes remonta às primeiras civilizações da Antiguidade. A palavra Panteão deriva de Pan (todo) e Théos (deus) e significa o templo dedicado a todos os deuses. Em Roma, construiu-se um templo com o objetivo de ser consagrado a todos os deuses. Era o Pantheon. No decorrer da história, o Panteão passou a designar o local onde se depositavam os restos mortais de homens ilustres e notáveis, que prestaram grandes serviços à Pátria.

Na França, em 1791, o processo revolucionário transformou a Igreja de Santa Genoveva no Panteão moderno, como forma de cultuar os grandes homens, com a legenda "Aos grandes homens, a Pátria reconhecida". ${ }^{3}$ Assim, os deuses e santos são substituídos pelos "heróis nacionais" (Bonnet, 1998). Estava instituído o Panteão moderno, cujo modelo passou a ser copiado por outros países. É o caso, por exemplo, do Panteão nacional português, formado pela Igreja de Santa Engrácia e pelo Mosteiro de Santa Cruz, que se localiza em Lisboa e passou a ter essa função em 1916. Também em Portugal localiza-se o Panteão dos Bragança, lugar onde descansam muitos dos monarcas e príncipes da quarta e última dinastia real portuguesa.

Em vários outros países do mundo, monumentos históricos foram construídos com a finalidade de homenagear seus benfeitores e proporcionar aos cidadãos o reconhecimento dos seus heróis nacionais. Muitos desses monumentos, embora consagrados à memória de apenas um personagem histórico, ao receberem os restos mortais, passaram a ter a denominação de Panteão. $\mathrm{O}$ mais certo, talvez, seria chamá-lo de mausoléu. O Panteão nacional pressupõe a consagração de vários personagens históricos alçados à condição de heróis da Pátria.

\section{O Panteão na História do Brasil: o culto cívico AOS GRANDES HOMENS}

No decorrer de nosso processo histórico, já existiram ideias e propostas acerca da construção de panteões cívicos em homenagem a determinadas figuras da História Pátria. Algumas delas surgiram no âmbito de discussões no Congresso Nacional, como foi o caso já anteriormente citado, em que se 
discutiu quem deveria ser considerado o "verdadeiro" fundador da República no Brasil - o civil e professor de orientação positivista Benjamin Constant, ou o militar e ex-monarquista Marechal Deodoro da Fonseca.

Na verdade, a instituição do regime republicano de governo fez proliferar na então capital da República, a cidade do Rio de Janeiro, a construção de monumentos históricos dedicados ao culto de determinados fatos que serviriam para a legitimação do novo regime. No entanto, conforme assinalamos em outro trabalho, ${ }^{4}$ essa prática de construção de monumentos históricos remonta ao processo de formação dos Estados nacionais, que emergiram, com maior intensidade, a partir da segunda metade do século XIX. Assim, assistiu-se em todo o mundo ocidental ao processo de construção de estátuas e monumentos históricos em praças públicas.

Num esforço para promover a "pedagogia da nação", construíram-se vários monumentos históricos que evocavam personagens e fatos históricos marcantes, dignos de registro à posteridade. No Brasil, em especial, seguindo a tradição francesa da "estatuomania" (Agulhon, 1998), foram edificados inúmeros monumentos a partir do ano de 1862, com a inauguração da estátua equestre do imperador d. Pedro I, na Praça Tiradentes. A este se seguiram outros, principalmente durante o período republicano, cujo lócus privilegiado foi a cidade do Rio de Janeiro, então capital do país (Knauss, 1991).

No Brasil, temos alguns panteões mais conhecidos, construídos no decorrer da história, como o Panteão dos Andradas, em Santos (SP), o Panteão de Duque de Caxias, no Rio de Janeiro (RJ), o Panteão dos Inconfidentes, também conhecido como Museu da Inconfidência, em Ouro Preto (MG), e o Panteão da Independência, em São Paulo (SP), além do Panteão da Pátria e da Liberdade Tancredo Neves, em Brasília (DF).

\section{O Panteão dos Andradas (Santos, SP)}

Na cidade de Santos (SP), foi inaugurado em 7 de setembro de 1923 um panteão dedicado à memória dos irmãos Andrada, considerados "filhos ilustres" dessa cidade pelo papel que desempenharam no contexto do processo de independência do país. Nele encontram-se os restos mortais de José Bonifácio e de seus irmãos Martim Francisco e Antônio Carlos. 
Na historiografia brasileira, José Bonifácio é considerado o grande articulador de nossa emancipação política, tendo sido consagrado com o epíteto de "O Patriarca da Independência". Seu nome também está inscrito no livro dos heróis da Pátria. Os outros dois irmãos Andrada também participaram da vida política do Império, tendo sido eleitos deputados constituintes para a Assembleia de 1823, dissolvida pelo imperador Pedro I.

\section{O Panteão dos Inconfidentes (Ouro Preto, MG)}

O Governo Vargas reforçou a construção do mito do herói nacional em torno de Tiradentes e dos demais inconfidentes, já iniciado desde os primeiros governos da República. Por decreto presidencial de 1936, Vargas determinou que os restos mortais dos inconfidentes, degredados para a África, fossem repatriados e depositados em Ouro Preto, em culto cívico nacional. Assim, foi inaugurado em 21 de abril de 1942, em lembrança aos 150 anos da decretação da sentença condenatória dos inconfidentes, o Museu da Inconfidência, com a instalação do Panteão contendo 14 lápides funerárias, 13 ocupadas pelas ossadas dos inconfidentes repatriadas do continente africano e uma vazia, dedicada aos participantes do movimento cujos corpos não foram localizados.

O Panteão dos Inconfidentes está situado na praça Tiradentes, na antiga Casa de Câmara e Cadeia de Vila Rica, atual Ouro Preto, Minas Gerais, em belíssimo prédio remanescente da arquitetura barroca colonial do século XVIII. Além dos despojos dos inconfidentes, esse panteão também abriga o túmulo de Maria Doroteia Joaquina de Seixas, a célebre Marília de Dirceu, do poeta Tomaz Antônio Gonzaga, e um memorial fúnebre de Bárbara Heliodora da Silveira, esposa e incentivadora de Alvarenga Peixoto. Dos inconfidentes mineiros, apenas o nome de Tiradentes está inscrito no Livro dos Heróis, no Panteão da Pátria em Brasília (DF).

A historiadora da arte Maria Alice Milliet sintetiza, com muita propriedade, esse momento de nossa história com a inauguração do Museu da Inconfidência e a consagração de Tiradentes como o verdadeiro mártir da nação brasileira. Diz ela:

Enfim a redenção! Ainda que mortos, retornam os inconfidentes à terra da qual saíram prisioneiros. São agora heróis. Em torno do mausoléu e do museu cons- 
trói-se um cenário maior. O propósito de recuperar o passado colonial para integrá-lo à cultura nacional e de fazê-lo reunindo história e arte converte-se numa das mais eficientes realizações de Patrimônio durante o Estado Novo. Nessa construção, o Museu da Inconfidência de Ouro Preto é pedra fundamental. Primeiro museu instituído fora da capital federal, o Sphan associa arquitetura, obras de arte e documentos históricos a fim de configurar uma memória e fundar uma tradição. (Milliet, 2001, p.123-124)

\section{O Panteão de Caxias (Rio de Janeiro, RJ)}

Inaugurado em 1949, está localizado na avenida Presidente Vargas, no Rio de Janeiro (RJ), em frente ao prédio do antigo Ministério da Guerra. Além de abrigar os restos mortais de Luís Alves de Lima e Silva, o Duque de Caxias, e os de sua esposa Ana Luisa de Loreto Carneiro Viana, duquesa consorte de Caxias, no panteão encontram-se a biografia do patrono do Exército e alguns de seus objetos, tais como o sabre, recebido pela vitória na Guerra do Paraguai, uma coroa ducal feita em 1950, lápides e insígnias.

O Duque de Caxias ${ }^{5}$ é considerado o Patrono do Exército brasileiro, e sua data de nascimento - 25 de agosto - é consagrada ao "Dia do Soldado", resultando em uma efeméride bastante comemorada pelas Forças Armadas. Depois de Tiradentes, o Duque de Caxias é um dos heróis mais cultuados pela nação brasileira, e seu nome também está inscrito no livro dos heróis da Pátria.

\section{O Panteão da Independência (SÃo Paulo, SP)}

Construído em 1952, esse Panteão está localizado no Monumento à Independência, que foi edificado em comemoração ao centenário de nossa emancipação política. Ele fica próximo às margens do riacho do Ipiranga, em São Paulo, e abriga em seu interior os restos mortais de Pedro I, de sua primeira esposa, imperatriz Leopoldina, e de sua segunda esposa, dona Amélia, todos trasladados de Lisboa por ocasião das comemorações alusivas aos 150 anos da Independência do Brasil, fato celebrado com pompa pelo regime militar, em 1972. Sobre o tampo onde estão os despojos do imperador, há a imagem da coroa imperial, uma reprodução da espada usada em 7 de setembro de 1822 e a representação simbólica da primeira Constituição política do Império do 
Brasil, outorgada em 1824. Os visitantes deparam com imponente decoração e com o histórico da Família Real Portuguesa.

\section{O Panteão da Liberdade e da Democracia Tancredo Neves (Brasília, DF)}

Em meio ao processo de redemocratização vivido pelo país após o regime militar (1964-1985), a ideia de se construir um monumento histórico dedicado aos "heróis nacionais" é retomada pelo Poder Público. A proposta ganhou força na ação do então governador do Distrito Federal, José Aparecido de Oliveira, como forma de prestar uma homenagem póstuma ao presidente eleito Tancredo Neves, que morreu antes de assumir o cargo maior do país, provocando verdadeira comoção nacional.

Segundo relatos de José Aparecido de Oliveira, ${ }^{6}$ a ideia de construção do Panteão surgiu no Palácio do Planalto, quando da realização das cerimônias fúnebres diante do corpo do presidente eleito Tancredo Neves alçado pelos braços de jovens soldados do Exército Nacional. Na Praça dos Três Poderes, com a concepção arquitetônica inovadora de Oscar Niemeyer, construiu-se, sob o formato de uma pomba, um monumento inspirado nos ideais de liberdade e democracia.

O Panteão da Pátria, localizado na capital da República, foi inaugurado no dia 7 de setembro de 1986, data máxima da nacionalidade, e nele se encontra um livro de aço "onde ficarão gravados para a eternidade os nomes dos que combateram e morreram para que todos os brasileiros fossem livres em sua pátria soberana" (Panteão da Pátria, folheto explicativo). Assim, o Panteão da Pátria recebe o pomposo nome de "Panteão da Liberdade e da Democracia Tancredo Neves".

Segundo o Instituto de Arquitetos do Brasil, Departamento do Distrito Federal (IAB-DF),

O conjunto do Panteão da Liberdade e da Democracia foi criado para comemorar a redemocratização do país, registrar a morte de Tancredo Neves e homenagear os heróis nacionais, especialmente, Tiradentes. Inaugurado em 7 de setembro de 1986, o monumento tem forma única. Para alguns, quando visto de frente, lembra uma pomba (ou duas); para outros, sugere dois troncos de pirâmides, in- 
vertidos e engastados. O volume é opaco, todo revestido de placas de mármore, apenas rasgado em uma de suas faces pelo vitral de Marianne Peretti. A construção foi implantada na campina circunvizinha da Praça dos Três Poderes, e a ela ligada por meio de uma passarela.

No interior, bastante escuro e cerimonioso, um hall de distribuição (com mural de Athos Bulcão), um pequeno auditório inferior e o salão superior (com o painel Inconfidência Mineira, de João Câmara, e o Livro de Aço onde estão registrados os nomes dos Heróis da Pátria).

Complementando o conjunto, Niemeyer projetou quatro grandes elementos escultóricos, que foram distribuídos na campina: o Monumento do Fogo Simbólico, ou Pira da Pátria, e três painéis curvos que - segundo os guias locais - representam Exército, Marinha e Aeronáutica a proteger nossa democracia. (Guia de obras..., 2010, p.78)

Diferentemente de outros panteões cívicos, o Panteão da Liberdade e da Democracia Tancredo Neves não contém os restos mortais dos heróis nacionais. Lá consta um livro de aço, denominado "Livro dos Heróis da Pátria", com o nome dos brasileiros já falecidos que, em vida, sobressaíram-se em seus ofícios em favor do país. Os nomes dos homenageados estão inscritos nesse livro de aço, no qual lhes é concedido o atributo de "Heróis da Pátria". Constam, em cada página de metal, seus nomes e biografias.

A princípio, não havia nenhum ato normativo que estabelecesse os critérios mínimos para a concessão do título de "Herói da Pátria". A partir da Lei $\mathrm{n}^{\circ} 11.597$, de 29 de novembro de 2007 (originalmente Projeto de Lei 6.345/2005, de autoria do senador Marco Maciel - DEM/PE), a inscrição no Livro dos Heróis da Pátria passa a ser regulamentada por alguns critérios básicos. A escolha deverá se proposta por Lei decorridos 50 anos da morte ou da presunção de morte do homenageado, à exceção de brasileiros mortos ou presumidamente mortos em campo de batalha.

A indicação de determinado nome pode ser feita por qualquer parlamentar (deputado ou senador), pelo Poder Executivo e até por iniciativa popular, mediante a apresentação de um projeto de lei. Para que se torne lei, o projeto precisa ser votado pelas duas Casas Legislativas e depois sancionado pelo presidente da República. Até o momento, os seguintes brasileiros têm status de Heróis da Pátria: 
- Alferes Joaquim José da Silva Xavier, o Tiradentes;

- Marechal Manuel Deodoro da Fonseca;

- Zumbi dos Palmares;

- D. Pedro I;

- Plácido de Castro;

- Luís Alves de Lima e Silva, o Duque de Caxias;

- Almirante Joaquim Marques Lisboa, Marquês de Tamandaré;

- Francisco Alves Mendes Filho, o Chico Mendes;

- Almirante Barroso;

- José Bonifácio de Andrada e Silva;

- Marechal-do-Ar Alberto Santos Dumont;

- Frei Joaquim do Amor Divino Rabelo, o Frei Caneca;

- Marechal Osório;

- Ildefonso Pereira Correia, o Barão de Serro Azul;

- Antônio de Sampaio, o Brigadeiro Sampaio;

- Sepé Tiaraju;

- Anna Justina Ferreira Nery;

- Padre José de Anchieta;

- José Hipólito da Costa Furtado de Mendonça;

- Getúlio Dornelles Vargas;

- Heitor Villa-Lobos;

- Padre Roberto Landell de Moura;

- Ana Maria de Jesus Ribeiro, mais conhecida como Anita Garibaldi;

- João de Deus do Nascimento, Lucas Dantas de Amorim Torres, Manuel Faustino Santos Lira e Luís Gonzaga das Virgens e Veiga, líderes da Revolta dos Búzios;

- Martins, Miragaia, Dráusio e Camargo (MMDC), heróis paulistas da Revolução Constitucionalista de 1932;

- Barão do Rio Branco; 
- Francisco Barreto de Menezes, João Fernandes Vieira, André Vidal de Negreiros, Henrique Dias, Antônio Filipe Camarão e Antônio Dias Cardoso - líderes da Insurreição Pernambucana;

- Júlio Cezar Ribeiro de Souza;

- Domingos Martins;

- Seringueiros Soldados da Borracha.

Desde 1989, quando se deu a primeira inscrição dos nomes de Tiradentes e Deodoro da Fonseca no Panteão da Pátria, através da Medida Provisória n ${ }^{\circ}$ 105, de 13 de novembro de 1989, por ocasião das comemorações alusivas ao bicentenário da morte do mártir da Inconfidência e do centenário da República no Brasil, temos presenciado a iniciativa por parte do Executivo e de parlamentares propondo a inscrição de nomes para figurar no "Livro dos Heróis da Pátria”.

Apesar da existência da Lei no 11.597, de 2007, que "dispõe sobre a inscrição de nomes no Livro dos Heróis da Pátria”, consideramos que falta uma maior discussão com os diferentes segmentos da sociedade sobre quem deve ocupar um lugar de destaque no Panteão nacional. No nosso entendimento, os inúmeros projetos de lei apresentados que sugerem a inscrição de nomes para figurar no Livro dos Heróis da Pátria banalizaram a concessão desse título, e a sociedade brasileira passa ao largo dessa discussão, ficando sua análise restrita ao debate parlamentar e aos interesses meramente locais e regionais. Muitos nomes escolhidos são praticamente ignorados pela população, não passando de "vultos e personalidades" que fazem parte de uma história meramente local. Quem foram, por exemplo, Ildefonso Pereira Correia, Júlio Cezar Ribeiro de Souza, Padre Roberto Landell de Moura e Domingos Martins? Que "fatos heroicos" protagonizaram ou serviços à nação brasileira prestaram para merecerem o título de "heróis nacionais"? O que dizer da inscrição de um grupo coletivo denominado "Seringueiros Soldados da Borracha" no livro dos heróis da Pátria?

Se por um lado a História é um processo de construção coletiva, consideramos, também, que toda nação que se preza deve cultuar seus líderes e fatos marcantes de sua história, sem o que não se cria entre os nacionais o sentimento de pertencimento e identidade. Assim, de certa forma, há determinados setores do governo e da sociedade que veem a instituição de homenagens a 
determinadas figuras da História Pátria como instrumento de afirmação da cidadania e de valorização da identidade nacional.

Como bem afirmou o historiador José Murilo de Carvalho:

Heróis são símbolos poderosos, encarnações de ideias e aspirações, pontos de referência, fulcros de identificação coletiva. São, por isso, instrumentos eficazes para atingir a cabeça e o coração dos cidadãos a serviço da legitimação de regimes políticos. Não há regime político que não promova o culto de seus heróis e não possua seu panteão cívico. (Carvalho, 1990, p.55)

\section{O Panteão da PÁtria Na escola: os heróis NACIONAIS NA LITERATURA DIDÁTICA}

Além do Panteão, como monumento símbolo da pedagogia do civismo, os heróis encontraram nos livros didáticos, mediante reprodução de suas fotos ou quadros, local privilegiado em que pudessem ser vistos e suas ações enaltecidas, servindo de modelo às novas gerações. Na verdade, o culto cívico aos heróis nacionais também é instrumento de afirmação da identidade nacional, seja em praça pública, seja nas comemorações cívicas, seja na literatura escolar.

A República recém-implantada no Brasil (1889) via na escola uma poderosa instância para a formação do novo cidadão republicano. Tratava-se, pois, de formar não mais o súdito do Império, mas um cidadão que valorizasse e amasse a Pátria, consciente de seus direitos e deveres perante a nação brasileira. Assim, o ensino da História e a chamada Instrução Cívica foram componentes indispensáveis nessa tarefa. Para atender essa demanda, surgiram diversos livros destinados à escola e que se tornaram verdadeiros "cânones literários". Definimos cânone literário escolar como o livro que teve adoção contínua na escola, com sucessivas edições e tiragens consideráveis de exemplares, tendo sido leitura obrigatória de várias gerações de crianças, adolescentes e jovens.

Esses livros foram escritos por expressivos nomes da intelligentsia brasileira, que tinham assento nas academias, associações literárias e científicas, entre as quais se destacam o Instituto Histórico e Geográfico Brasileiro (IHGB), o Colégio Pedro II e a Academia Brasileira de Letras (ABL). Eram, sobretudo, bacharéis e jornalistas que se dedicavam à escrita nos principais periódicos e 
semanários locais. Assim, vários intelectuais, comprometidos com a causa da educação, pois viam nela a "regeneração da nação", foram responsáveis pela escrita de livros escolares adotados nas escolas primárias e lidos pela infância brasileira nos primeiros decênios da República. Destaque especial deve ser dado a algumas produções didáticas de membros da Academia Brasileira de Letras. Estamos nos referindo, em especial, aos seguintes livros e seus respectivos autores: História do Brasil ensinada pela biografia de seus heróis. Livro para as classes primárias (Silvio Romero, $1^{\text {a }}$ edição: 1890); Breviário Cívico (Coelho Netto, $1^{\text {a }}$ edição: 1921) e História do Brasil para crianças (Viriato Corrêa, $1^{\text {a }}$ edição: 1934. Silvio Romero (1851-1914) e Coelho Neto (1864-1934) foram membros-fundadores da ABL, e Viriato Corrêa (1884-1967) ingressou na Academia no ano de 1938, sendo o primeiro autor de literatura infantil a entrar no quadro dos “imortais” da ABL (Oriá, 2011).

Esses manuais escolares "construíram" não um monumento de pedra e bronze, mas um Panteão impresso em papel na escola republicana, mediante a memorização da tríade "datas-fatos-vultos nacionais", indispensável à formação do sentimento patriótico que as elites políticas e educacionais almejavam para a formação do cidadão e esperavam da então escola primária brasileira (Carretero; González, 2004).

Que nomes merecem entrar no Panteão da Pátria na escola? Que filhos ilustres devem ser exaltados por suas virtudes e ações como exemplo para as novas gerações de brasileiros? Nem todos os brasileiros são dignos dessa homenagem. Nesse sentido, o Panteão da Pátria a ser lembrado e cultuado pela escola é composto quase que exclusivamente por elementos pertencentes à elite branca letrada ou aqueles que possuíam o poder político-institucional. Não há nenhuma mulher de destaque da nossa história, nem mesmo ligada à elite política. Temos, assim, um Panteão que reproduz uma história assexuada, na qual os heróis são, na sua grande maioria, homens.

No entanto, há, em todos os livros analisados, a construção mítica do "Mártir da Independência" e herói republicano por excelência - Joaquim José da Silva Xavier, o Tiradentes. ${ }^{8}$ Sua imagem construída pelos republicanos é a de um "Cristo cívico" (Carvalho, 1990), que, a exemplo do líder religioso, morreu em sacrifício da Pátria e pela liberdade do país. Tanto assim é que Tiradentes é o Patrono da Nação brasileira (Lei no 4.897, de 1965) e sua data de morte (21 de abril) é feriado em todo o território nacional. 
Por sua vez, os heróis nacionais encontraram na literatura didática, mediante a reprodução de sua biografia, fotos ou quadros, um local privilegiado em que pudessem ser vistos e suas ações enaltecidas pelas gerações mais novas. Nesse sentido, além dos monumentos históricos edificados em praça pública, um verdadeiro Panteão de papel impresso foi incorporado à cultura escolar brasileira (Julia, 2001).

Além do culto aos heróis nacionais, a escola republicana, como parte de seu projeto político-pedagógico, selecionou algumas datas festivas que deveriam ser comemoradas. Segundo Bittencourt (2003), o culto a heróis e a valorização de determinadas datas e efemérides relacionadas aos fatos históricos e mitos fundadores da nacionalidade tiveram na escola um espaço privilegiado para sua divulgação.

Que datas a escola primária, da primeira metade do século XX, deveria celebrar?

\section{As COMEMORAÇõeS E RITUAIS CÍVICOS NA ESCOLA}

Lembrar, esquecer e comemorar são ações de memória inerentes ao ser humano. Comemorar é típico das sociedades humanas. Não há país que, no seu processo de construção de identidade nacional, não promova e cultue seus fatos mais relevantes a serem lembrados à posteridade, seja através do registro de sua história, seja na edificação de monumentos, seja na celebração de datas comemorativas e rituais cívicos.

Quando se comemora um determinado fato ou acontecimento, o que está sendo colocado em jogo não é apenas o passado de uma sociedade, mas sim, como essa mesma sociedade quer se constituir no presente e projetar seu futuro. Daí porque Pierre Nora também considera que as datas comemorativas e os cultos e rituais a elas relacionados, são lugares de memória por excelência, ao permitirem o entrelaçamento entre passado-presente-futuro. Por sua vez, comemorar não significa apenas celebrar, mas, sobretudo, refletir sobre o passado a partir de seus usos políticos e demandas do tempo presente. (Ferreira, 2012, p.110)

Em vários momentos da história da civilização ocidental, sobretudo a partir do final do século XIX e início do século XX, tivemos importantes comemorações alusivas a fatos históricos significativos. A socióloga Lúcia Lippi faz uma análise precisa sobre as comemorações na História. Diz ela: 
O fim do século XIX foi marcado por inúmeras comemorações. Os Centenários das revoluções Americana e Francesa, os IV Centenários das viagens de Colombo e de Vasco da Gama, deram oportunidade aos povos do Ocidente de celebrar esses feitos do passado segundo as questões daquele presente. As exposições internacionais que acompanharam essas comemorações permitiram que cada povo, ao olhar para trás, afirmasse sua modernidade e seu papel em uma escalada evolutiva do ser humano, da barbárie à civilização.

As comemorações de datas nacionais seguem, grosso modo, uma mesma trajetória: organização de comissões executivas nacionais, campanhas de esclarecimento patriótico, organização de eventos cívicos, cortejos fluviais e marítimos, montagem de exposições, inauguração de monumentos, confecção de selos, medalhas, bandeiras e hinos. São esses atos mais frequentes que marcam as comemorações. (Oliveira, 2000, p.185-186)

No Brasil, a instituição de datas comemorativas sempre foi objeto de interesse por parte das elites políticas e intelectuais. Em última instância, era sempre o Estado, na sua função legiferante, que determinava que datas seus cidadãos poderiam comemorar.

Assim, a tradição das datas comemorativas remonta ao período imperial de nossa história. Logo após nossa emancipação política, o Estado monárquico encarregou-se de fixar um calendário cívico nacional. Isso ocorreu na primeira legislatura da Câmara dos Deputados, com a edição da Lei de 9 de setembro de 1826, que pontuou as seguintes datas dignas de serem comemoradas: 9 de janeiro, dia do "Fico"; 25 de março, data da outorga de nossa primeira Constituição; 3 de maio, que celebrava a chegada de Cabral ao Brasil e que foi estabelecida como a data oficial para a abertura anual dos trabalhos do Parlamento; 7 de setembro, dia da independência do país; e 12 de outubro, data natalícia de Pedro I e de sua aclamação como "Defensor perpétuo e imperador do Brasil”.

As datas oficiais mudam de acordo com os interesses do governo, da sociedade e de seus grupos organizados. Assim, logo após a proclamação da República, um dos primeiros atos do Governo Provisório foi o de editar o Decreto no 155 -B, de 14 de janeiro de 1890, em que assinalava as "festas públicas" que ele reconhecia como dignas de registro e comemoração. Por exemplo, as datas relacionadas à comemoração do nascimento do imperador Pedro I e à nossa primeira Constituição foram expurgadas do calendário nacional 
republicano. Nada que fizesse lembrar o período monárquico de nossa história, pois o regime recém-implantado ainda convivia com o "fantasma" do retorno da monarquia. Tratava-se, pois, de escolher símbolos, ícones, datas e heróis e construir novos monumentos para legitimar a República.

Sabemos, por experiência própria e evocando os tempos de infância, que a escola, desde os seus primórdios, foi o espaço privilegiado para a divulgação das datas comemorativas. Quem não se recorda das aulas de História e de Educação Moral e Cívica em que nos era exigida a memorização das datas e fatos históricos por ocasião das provas e das tão temidas arguições, onde trazíamos tudo "de cor", "na ponta da língua"?

A própria literatura escolar foi pródiga na elaboração de manuais e livros didáticos que traziam em seu bojo a enumeração das datas comemorativas e efemérides nacionais. Exemplo paradigmático é o livro do escritor e deputado federal Coelho Neto, intitulado Breviário Cívico, de 1921, que circulou pela escola brasileira até o final da década de 1950. Para Coelho Neto (1921, p.9),

As datas nacionais são as que celebram um culto tradicional da Humanidade (2 de novembro), as que comemoram um acontecimento de interesse universal ( $1^{\circ}$ de janeiro, 14 de julho, 12 de outubro); e as que, particularmente, se referem à nossa história, tendo influído no progresso e na civilização da Pátria Brasileira (24 de fevereiro - promulgação da Constituição da República; 21 de abril - Martírio de Tiradentes; 3 de maio de 1500 - Descobrimento do Brasil; 13 de maio de 1888 - Abolição da Escravidão; 7 de setembro de 1822 - Independência do Brasil e 15 de novembro - Proclamação da República).

Ao estudo e comemoração festiva das datas da nacionalidade, como elemento formador da cultura escolar, seguia-se a celebração de rituais cívicos na escola, aliada ao respeito e culto aos símbolos nacionais (Catroga, 2005). Geralmente, esses rituais cívicos na escola eram acompanhados de hasteamento solene da bandeira, seguido do cântico do Hino Nacional. Celebração máxima se dava por ocasião do 7 de setembro - data máxima da nacionalidade -, em que várias escolas participavam de um desfile, assemelhando-se a uma parada militar, numa exaltação ufanista do sentimento patriótico. 
À GUISA DE CONCLUSÃO: QUEM FAZ A HistóRIA?

Quem construiu a Tebas das sete portas?

Nos livros constam os nomes dos reis

Os reis arrastaram os blocos de pedra?

Tantos relatos

Tantas perguntas.

Bertolt Brecht, "Perguntas de um operário que lê"

A História humana não se desenrola apenas nos campos de batalha e nos gabinetes presidenciais. Ela se desenrola também nos quintais entre plantas e galinhas, nas ruas de subúrbios, nas casas de jogos, nos prostíbulos, nos colégios, nas usinas, nos namoros de esquinas. Disso eu quis fazer a minha poesia. Dessa matéria humilde e humilhada, dessa vida obscura e injustiçada, porque o canto não pode ser uma traição à vida, e só é justo cantar se o nosso canto arrasta consigo as pessoas e as coisas que não têm voz.

Ferreira Gullar

Durante muito tempo, o conhecimento histórico produzido - a Historiografia - e seu ensino nas escolas, academias e universidades privilegiou a figura do "herói" como sujeito único e exclusivo do processo histórico (Miceli, 1988; Fonseca, 2009). Essa visão conservadora e tradicional da História, reproduzida nos manuais e compêndios didáticos, trouxe consequências danosas para o ensino e a cultura política nacional.

Ao privilegiar a memorização de datas, fatos históricos e nomes de personagens, o ensino de História na escola fundamental acabou por incutir nos alunos uma visão de que o seu estudo pouco tem a contribuir para a formação da cidadania de nossas crianças, adolescentes e jovens. Reproduziu-se, assim, um ensino de História que nada tem a ver com as experiências sociais dos alunos e professores, negando-lhes, portanto, a dimensão de que eles são também sujeitos e agentes da transformação da sociedade. Nesse contexto, alunos e professores não percebiam a função social da História, ou seja, o quanto o estudo do passado possibilita uma melhor compreensão do presente por eles vivido. Esse fenômeno não é apenas nacional. Segundo Hook, em 
várias partes do mundo "a História de cada nação é representada à sua juventude em termos de explorações dos grandes indivíduos - míticos ou reais" (1962, p.15).

No âmbito da cultura política, ao privilegiar o culto à figura do "herói nacional”, criou-se, no imaginário coletivo da população brasileira, a ideia de que a solução para nossos inúmeros problemas sociais depende, única e exclusivamente, da ação isolada de um homem/mulher. Isso está muito presente e enraizado na cultura nacional, sobretudo em época de eleições, quando grande parcela da população está à espera do "salvador da Pátria", o "herói nacional”, que irá nos redimir de nosso passado e nos conduzir a um futuro glorioso.

Hoje, com o avanço teórico-metodológico das Ciências Sociais e a renovação do ensino de História, a Historiografia contemporânea considera que todos fazem a História, ou seja, todos somos sujeitos históricos. A História é um processo de construção coletiva, no qual todos participam: vencedores e vencidos, dominantes e dominados, governo e sociedade civil, as minorias étnicas, enfim, os diversos segmentos sociais do país.

Na produção do conhecimento histórico, que se dá sobretudo nos cursos de pós-graduação em História das Universidades brasileiras, a pesquisa realizada por historiadores e demais cientistas sociais tem levado em conta, nas últimas décadas, as diversas experiências de vida de homens e mulheres comuns que, no seu cotidiano de luta e trabalho, constroem a História deste país.

A História tradicional, que ressaltava a ação isolada e mistificadora dos "heróis nacionais", os feitos, fatos e realizações dos governantes, está totalmente superada. No que se refere à construção dos monumentos históricos e cívicos, no decorrer da história, Silvia Hunold Lara faz uma crítica contundente:

Na história que estamos acostumados a ouvir há sempre grandes homens: heróis, mártires, patriarcas e patronos que são glorificados em pedra e bronze, como no Monumento à Independência do Brasil. Austeros, solitários, brancos e bem nascidos, eles acabam encarnando toda a história, como se ela pudesse ser feita apenas por poucos indivíduos. (São Paulo, 1992, p.84)

Outra crítica que se pode fazer ao Panteão da Pátria e seu Livro dos Heróis é a quase total ausência de representantes do sexo feminino. Apenas duas mulheres - Anna Nery e Anita Garibaldi - figuram no Panteão da Liberdade e da 
Democracia. Pergunta-se: onde estão as mulheres que nos diferentes espaços da sociedade participaram do processo histórico nacional?

Para finalizar, nada melhor do que recorrer à música popular brasileira, que nos leva à reflexão acerca de nosso papel na história do país:

Ah, quem será o herói

Dessa nossa História

Que vai tecer o amanhã?

Quem será o herói

Quem será a força

Que a forca não pode calar?

João e Maria que se dão bom dia

É Dona Tereza que coloca a mesa

É o Waldemar que vai trabalhar

É Dona das Dores que nos manda flores

É o amigo Pedro que já não tem medo

Seu José que é de muita fé

Quem será o herói

Dessa nova História

Quem vai tecer o amanhã?

É quem faz cimento, quem carrega areia

Quem amassa o pão e ama a lua cheia

Sabe que a chuva é pra se molhar

João e Maria, Waldemar e Pedro

João e Tereza que é nossa das Dores

Joaquim José da Silva Xavier

Meu povo é meu herói

Ele é a força

Que a forca não pode calar.

(“Nosso Herói”, de Beto Guedes) 


\section{REFERÊNCIAS}

LIVROS E PERIÓDICOS:

AGULHON, Maurice. Histoire Vagabonde. Paris: Galimard, 1988. v.I.

ABREU, Regina. A fabricação do imortal: memória, história e estratégias de consagração no Brasil. Rio de Janeiro: Rocco, 1996.

BITTENCOURT, Circe. Identidade Nacional e Ensino de História do Brasil. In KARNAL, Leandro (Org.) História na sala de aula: conceitos, práticas e propostas. São Paulo: Contexto, 2003.

BONNET, Jean-Claude. Naissance du Panthéon: essai sur le culte des grands hommes. Paris: Fayard, 1998.

CANCLINI, Nestor Garcia. Consumidores e cidadãos: conflitos multiculturais da globalização. Rio de Janeiro: Ed. UFRJ, 1995.

CARLYLE, Tomás. Os Heróis. 2.ed. Lisboa: Guimarães Ed., 2002.

CARRETERO, Mário; GONZÁLEZ, Maria Fernanda. Imagénes históricas y construcción da la identidade nacional: una comparación entre la Argentina, Chile y Espana. In: CARRETERO, Mario; VOSS, James F. (Comp.) Aprender y pensar la historia. Buenos Aires: Amorrotu, 2004.

CARVALHO, José Murilo de. Tiradentes: um herói para a República In: CARVALHO, José Murilo de. A formação das almas: o imaginário da República no Brasil. São Paulo: Companhia das Letras, 1990.

Nação imaginária: memória, mitos e heróis. In: NOVAES, Adauto (Org.) A crise do Estado-Nação. Rio de Janeiro: Civilização Brasileira, 2003.

CATROGA, Fernando. Nação, mito e rito. Fortaleza: Nudoc-UFC, 2005.

COELHO NETTO, Paulo. Breviário Cívico. 3.ed. Rio de Janeiro: Organização Simão, 1957.

CORRÊA, Viriato. A História do Brasil para crianças. 21.ed. São Paulo: Cia Ed. Nacional, 1957.

ÉDITIONS DU PATRIMOINE. Les grands hommes du Panthéon. Paris, 1999.

ENDERS, Armelle. Os vultos da nação: fábrica de heróis e formação dos brasileiros. Rio de Janeiro: Ed. FGV, 2014.

ESTUDOS HISTÓRICOS. Heróis Nacionais. Rio de Janeiro: FGV, v.14, n.25, 2000.

FÉLIX, Loiva; ELMIR, Cláudio (Org.) Mitos e heróis: construção de imaginários. Porto Alegre: Ed. Universidade/UFRGS, 1998.

FERREIRA, Marieta de Moraes. Demandas sociais e história do tempo presente. In: VARELLA, Flávia et al. (Org.) Tempo presente e usos do passado. Rio de Janeiro: Ed. FGV, 2012. 
FONSECA, Thaís Nívia de Lima. Da infâmia ao Altar da Pátria: memória e representações da Inconfidência Mineira e de Tiradentes. Tese (Doutoramento) - Faculdade de Filosofia, Letras e Ciências Humanas, Universidade de São Paulo. São Paulo, 2001.

Os heróis nacionais para crianças: ensino de história e memória nacional. In: ROCHA, Helenice et al. A escrita da história escolar: memória e historiografia. Rio de Janeiro: Ed. FGV, 2009.

GUIA DE OBRAS DE OSCAR NIEMEYER: Brasília 50 anos. Brasília: Instituto dos Arquitetos do Brasil; Câmara dos Deputados; Edições Câmara, 2010.

HOOK, Sidney. O herói na História. Rio de Janeiro; Zahar, 1962. (Col. Biblioteca de Cultura Histórica).

JULIA, Dominique. A cultura escolar como objeto histórico. Revista Brasileira de História da Educação, Campinas, SP: Autores Associados, n.1, jan.-jun. 2001.

KNAUSS, Paulo (Coord.) Cidade vaidosa: imagens urbanas do Rio de Janeiro. Rio de Janeiro: Sette Letras, 1999.

MICELI, Paulo. O mito do Herói Nacional. São Paulo: Contexto, 1988. (Coleção Repensando a História).

MILLIET, Maria Alice. Tiradentes: o corpo do herói. São Paulo: Martins Fontes, 2001.

MOTTA, Baptista da. In: Sessão da Câmara dos Deputados, Anais. Rio de Janeiro. Imprensa Oficial. 9 nov. 1911.

NORA, Pierre. Entre Memória e História: a problemática dos lugares. História e Cultura. Projeto História (Revista do Programa de Estudos Pós-Graduados em História do Departamento de História da PUC-SP), São Paulo, n.10, dez. 1993.

OLIVEIRA, Lúcia Lippi. As festas que a República manda guardar. Estudos Históricos, Rio de Janeiro, v.2, n.4, 1989.

. Imaginário histórico e poder cultural: as Comemorações do Descobrimento. Estudos Históricos, Rio de Janeiro, v.14, n.26, 2000.

. A construção do herói no imaginário brasileiro de ontem e de hoje. In: . História cultural: experiências de pesquisa. Porto Alegre: Ed. UFRGS, 2003.

OTÁVIO, Rodrigo. Festas Nacionaes. Educação Cívica (com uma introdução de Raul Pompéia). Rio de Janeiro: F. Briguiet \& Cia., 1893.

ROMERO, Sylvio. História do Brasil ensinada pela biographia de seus heróes. Livro para as classes primárias. Rio de Janeiro: Francisco Alves, 1890.

ORIÁ, Ricardo. A História em praça pública: a leitura da cidade através de seus monumentos históricos. Ciências e Letras, Revista da Faculdade Porto-Alegrense de Educação, Ciências e Letras, Porto Alegre, n.27, jan.-jun. 2000. 
ORIÁ, Ricardo. O Brasil contado às crianças: Viriato Corrêa e a literatura escolar brasileira (1934-1961). São Paulo: Annablume, 2011.

PANTEÃO DA PÁTRIA, folheto explicativo. Brasília: Governo do Distrito Federal, s.d.

RIBEIRO, Maria Eurydice de Barros. Memória em Bronze: Estátua Eqüestre de D. Pedro I. In: KNAUSS, Paulo (Coord.) Cidade vaidosa: imagens urbanas do Rio de Janeiro. Rio de Janeiro: Sette Letras, 1999.

RIEGL, Aloïs. Le culte moderne des monuments: son essence e sa genèse. Paris: Ed. du Seuil, 1994.

SALGUEIRO, Valéria. De pedra e bronze: um estudo sobre monumentos. O Monumento a Benjamin Constant. Niterói, RJ: Ed. UFF, 2008.

SÃO PAULO (cidade). Secretaria Municipal de Cultura. Departamento de Patrimônio Histórico. Pátria amada esquartejada. São Paulo, 1992.

SOUZA, Adriana Barreto de. Duque de Caxias: o homem por trás do monumento. Rio de Janeiro: Civilização Brasileira, 2008.

. Um herói para a juventude: o Duque de Caxias nas biografias e livros didáticos. In: ROCHA, Helenice et al. A escrita da história escolar: memória e historiografia. Rio de Janeiro: Ed. FGV, 2009.

\section{LEGISLAÇÃO CONSULTADA:}

CONSTITUIÇÃO FEDERAL DE 1891 (art. 8º das Disposições Transitórias).

Decreto-Lei no 35, de 1937, que "organiza a proteção do patrimônio histórico e artístico nacional".

Decreto-Lei no 1.706, de 1939, que "institui o Livro do Mérito".

Lei no 4.897, de 1965, que "declara Joaquim José da Silva Xavier, o “Tiradentes”, patrono da nação brasileira”.

Lei $\mathrm{n}^{\circ}$ 7.919, de 11 dez. 1989, que "dispõe sobre a inscrição do nome de Tiradentes e Deodoro da Fonseca no Livro dos Heróis da Pátria”.

Lei no 11.597, de 2007, que "dispõe sobre a inscrição de nomes no Livro dos Heróis da Pátria”.

Projeto de Lei no 4.087, de 1989, que "dispõe sobre a homenagem à memória de brasileiros considerados Heróis da Pátria”.

\section{NOTAS}

${ }^{1}$ Hoje é o Museu Casa Benjamin Constant, que integra o Instituto Brasileiro de Museus (Ibram), do Ministério da Cultura (MinC). 
${ }^{2}$ Para Pierre Nora, com o advento da modernidade, caracterizado pela aceleração da história, cada vez mais, o cotidiano afasta-se das vivências da tradição e dos costumes. A memória deixa de ser encontrada no próprio tecido social e passa a necessitar de lugares especiais para ser guardada e preservada em seus laços de continuidade. São os lugares de memória encarregados dessa função de manutenção dos liames sociais, frente à ameaça do esquecimento. Para Nora, "Os lugares de memória nascem e vivem do sentimento que não há memória espontânea, que é preciso criar arquivos, que é preciso manter aniversários, organizar celebrações, pronunciar elogios fúnebres, notariar atas, por que essas operações não são naturais ... Os lugares de memória são, antes de tudo, restos”. Ele classifica esses lugares de memória em três categorias: lugares topográficos (arquivos, bibliotecas, monumentos, museus; lugares simbólicos (comemorações, aniversários, emblemas, símbolos nacionais); lugares funcionais (manuais didáticos, autobiografias, associações).

${ }^{3}$ Lema contido no pórtico de entrada do Panteão francês: "Aux grands hommes la patrie reconnaisante” (ÉDITIONS DU PATRIMOINE, 1999, p.3).

${ }^{4}$ Etimologicamente, a palavra "monumento" é de origem latina e provém do verbo "monere”, que significa lembrar. Assim, seguindo a clássica definição do historiador da arte Alöis Riegl (1994), monumento é toda obra criada pela mão do homem e construída com a finalidade de conservar sempre viva e presente, na consciência das gerações futuras, a lembrança de determinada ação ou de uma existência. Sobre a construção de monumentos históricos, ver nosso trabalho ORIÁ, 2000.

${ }^{5}$ Sobre o culto cívico a Caxias, consultar os excelentes trabalhos da historiadora Adriana Barreto de Souza (SOUZA, 2008; 2009).

${ }^{6}$ Posteriormente já como ministro da Cultura, José Aparecido de Oliveira encaminhou ao então presidente da República, José Sarney, uma exposição de motivos que fundamentou a proposta de inscrição de nomes brasileiros falecidos que deveriam constar no Panteão da Pátria. Trata-se do Projeto de Lei $\mathrm{n}^{\circ}$ 4.087, de 1989, que dispõe sobre a homenagem à memória de brasileiros considerados "Heróis da Pátria". O referido projeto tramitou na Câmara dos Deputados, tendo sido apreciado na primeira das comissões permanentes - Comissão de Constituição e Justiça e Redação -, que o rejeitou por considerar injurídico, visto que essa homenagem poderia ser tratada em nível de decreto pelo Poder Executivo. Nesse sentido, a proposição foi arquivada, sem que fosse analisado seu mérito pela Comissão de Educação e Cultura da Câmara dos Deputados.

${ }^{7}$ A prática de homenagem a brasileiros notáveis também não é recente na história do país. Getúlio Vargas, em pleno Estado Novo (1937-1945), instituiu o "Livro do Mérito”, “destinado a receber a inscrição dos nomes das pessoas que, por doações valiosas ou pela prestação desinteressada de serviços relevantes, hajam notoriamente cooperado para o enriquecimento do patrimônio material ou espiritual da Nação e merecido o testemunho público do seu reconhecimento" (art. $1^{\circ}$ do Decreto-Lei no 1.706, de 1939). Foram inscritos no Livro do Mérito os cientistas Vital Brasil e Cardoso Fontes, os juristas Clóvis Beviláqua e Francisco Mendes Pimentel, o sertanista general Cândido Mariano Rondon, pessoas dedicadas à assistência social como Rafael Levi de Miranda e Sinhá Junqueira e Guilherme 
Guinle, considerado um dos maiores doadores de obras de arte e peças numismáticas aos museus brasileiros.

${ }^{8}$ Sobre a construção simbólica da figura de Tiradentes como mártir da República e sua elevação à categoria de "herói nacional", consultar os seguintes trabalhos: CARVALHO, 1990; MILLIET, 2001; e FONSECA, 2001.

Artigo recebido em 24 de setembro de 2014. Aprovado em 23 de outubro de 2014. 